УДК $338.2: 502.3$

DOI: $10.15673 /$ fie.v13i3.2127

\author{
Нікішина О.В. \\ доктор економічних наук, старший науковий співробітник \\ завідувач відділу ринкових механізмів та структур \\ Інститут проблем ринку та економіко-екологічних досліджень НАН України \\ Французький бульвар, 29, м. Одеса, Україна, 65044 \\ E-mail: ksenkych@gmail.com \\ ORCID ID: 0000-0002-7172-3551
}

\title{
ДІАГНОСТИКА ВПЛИВУ ІНСТИТУЦІЙНОГО СЕКТОРУ ДОМОГОСПОДАРСТВ НА СТАЛИЙ РОЗВИТОК ЕКОНОМІКИ УКРАЇНИ *
}

Стаття присвячена обґрунтуванню методичного забезпечення діагностики впливу сектору домашніх господарств на сталий розвиток національної економіки у координатах Цілей сталого розвитку 1 , $2,6,7,10,12$. Наголошено, що даний методичний базис $є$ складовою загальної методології діагностики домінант інвестиційно-інноваційної політики природокористування національної економіки. Доповнено базові функції домогосподарств у ринковій економіці екологічною та соціальною функціями. Особливістю авторського методичного забезпечення $є$ інтеграція до національної системи індикаторів сталого розвитку низки секторальних показників, які дозволяють діагностувати тенденції сталого розвитку сектору домашніх господарств. На основі розроблених методичних положень проведено діагностику впливу інституційного сектору домогосподарств на сталий розвиток економіки України за 2015-2019 рр., що дозволило визначити місце і роль даного сектору у впровадженні Цілей сталого розвитку. На підставі результатів діагностики обґрунтовано головні тенденції і проблеми сталого розвитку сектору домогосподарств, прикладне значення методичного забезпечення для побудови системи багаторівневого моніторингу Цілей сталого розвитку в Україні.

Ключові слова: сектор, домогосподарства, господарства населення, Цілі сталого розвитку, діагностика, індикатори.

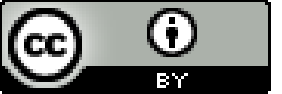

This work is licensed under a Creative Commons Attribution 4.0 International License http://creativecommons.org/licenses/by/4.0/
Постановка проблеми та її зв'язок з важливими науковими та практичними завданнями. Забезпечення сталого відтворювального розвитку національної економіки залежить від розвитку іiі суб'єктів господарювання, у т.ч. і сектору домашніх господарств. Категорія «домогосподарство» як інституційна одиниця з'явилося в Україні в 1990 р. разом із впровадженням Системи національних рахунків. У Законі України «Про всеукраїнський перепис населення» №2058-III від 19.10.2000 р. домогосподарство визначене як сукупність осіб, які спільно проживають в одному житловому приміщенні або його частині, забезпечують себе всім необхідним для життя, ведуть спільне господарство, повністю або частково об'єднують та витрачають кошти. Ці особи можуть перебувати у родинних стосунках або стосунках свояцтва, не перебувати у будь-яких з цих стосунків, або бути i в тих, і в ін. стосунках [1].

Головним призначенням сектору домашніх господарств є забезпечення робочою силою та здійснення кінцевого споживання [2]. В літературі категорія «домогосподарство» має декілька трактувань, водночас дослідженню даного терміну в природоко- ристуванні та сталому розвитку економіки приділено недостатньо уваги.

У контексті впровадження домінант інвестиційно-інноваційної політики природокористування (далі - IIПП) інституційний сектор домогосподарств доцільно розглядати як вагомий інструмент сталого розвитку, адже вони не лише споживають товари й послуги, а й виступають власниками і постачальниками всіх ресурсів - землі, праці, капіталу, підприємницьких здібностей. У системі Цілей сталого розвитку (далі - ЦСР) значною є роль домогосподарств у досягненні ЦСР 2 «Подолання голоду, розвиток сільського господарства», ЦСР 6 «Чиста вода та належні санітарні умови», ЦСР 7 «Доступна та чиста енергія», ЦСР 1 «Подолання бідності», ЦСР 10 «Скорочення нерівності», ЦСР 12 «Відповідальне споживання та виробництво». Актуальність дослідження обумовлена необхідністю розробки методичного забезпечення діагностики впливу домогосподарств на сталий розвиток економіки, як невід'ємної складової загальної методології діагностики домінант ІІПП національної економіки.

* Публікацію підготовлено в межах НДР «Домінанти інвестиційно-інноваційної політики природокористування національної економіки» за рахунок коштів бюджетної програми «Підтримка розвитку пріоритетних напрямів наукових досліджень» (КПКВК 6541230) 
Аналіз останніх публікацій по проблемі. Методичне забезпечення моніторингу ЦСР, адаптованих до України, висвітлено в Національній доповіді Міністерства економічного розвитку і торгівлі України [3], методичні підходи та рекомендації щодо оцінки домінант ІІПП у державному та регіональному вимірі розроблено Б.В. Буркинським [4], Н.М. Андрєєвою та Г.О. Тютюнник [5]. Питанням дослідження ролі і місця домогосподарств у системі національної економіки присвячено праці А.П. Бурляй, О.Л. Бурляй, О.О. Рябченко [6], Н.І. Кришеник [7], Т.О. Кізими [8], Д.В. Козачишиної та ін. науковців. Існуюче методичне забезпечення орієнтовано на діагностику процесів сталого розвитку на різних рівнях економічної системи (макро-, мезо- та мікрорівнях), водночас поза увагою науковців залишилося питання діагнос- тики ЦСР у розрізі секторів економіки, зокрема, інституційного сектору домогосподарств.

Формулювання цілей дослідження. Мета статті - обгрунтування функцій домогосподарств у системі національної економіки, розробка методичного забезпечення та проведення діагностики впливу інституційного сектору домогосподарств на сталий розвиток економіки України.

Виклад основних результатів та їх обгрунтування. Інституційний сектор домогосподарств $\epsilon$ невід'ємною складовою суспільства і учасником ІІПП (рис. 1). Таке уявлення базується на концепції «квадро-спіралі», яку розробили Караянніс Е.Г., Барт Т.Д. та Д.Ф.Дж. Кемпбелл, розширивши традиційну потрійну інноваційну спіраль шляхом включення до іiі складу суспільства та різних стейкхолдерів [9].

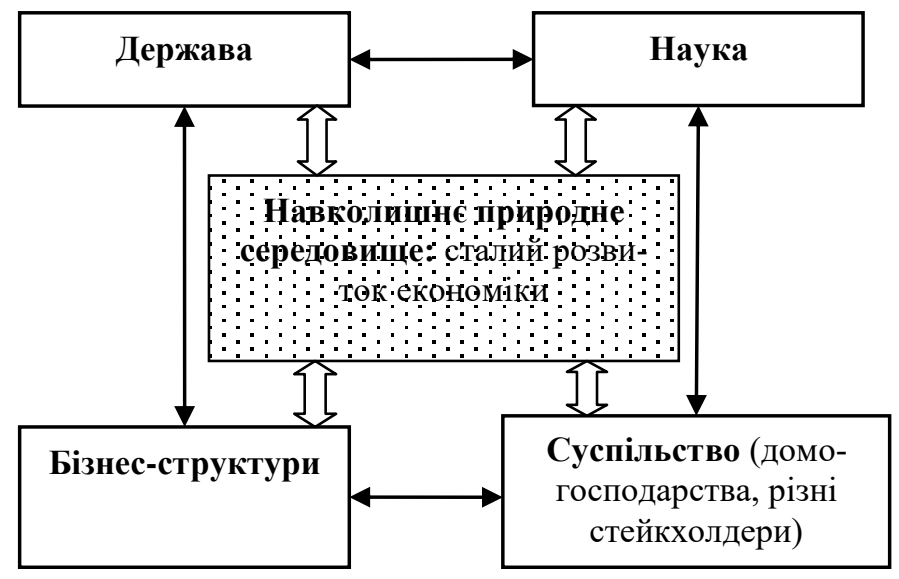

Рис. 1. Система взаємовпливів (на основі зворотного зв'язку) суб'єктів ІІПП та навколишнього природного середовища* *авторська розробка

Державні органи влади визначають вектор i пріоритети ІІПП «зверху», впроваджуючи певні обмежувальні та стимулюючі механізми раціонального природокористування, водночас суспільство реалізує цю політику «знизу», впливаючи на сталий розвиток національної економіки.

Учені виділяють п’ять головних функцій домогосподарств в економіці [6, 8]: постачальницька, виробнича, споживча, відтворювальна, заощаджувальна (табл. 1). Основною функцією даного інституційного сектору $є$ споживання, водночас він може здійснювати як ринкове, так і неринкове виробництво товарів і послуг. У площині сталого розвитку економіки пропонуємо доповнити перелік функцій домогосподарств екологічною та соціальними функціями.

Головні функції домогосподарств в ринковій економіці"

\begin{tabular}{|l|l|}
\hline \multicolumn{1}{|c|}{ Функції } & \multicolumn{1}{c|}{ Сутнісна характеристика } \\
\hline 1. Постачальницька & Постачання на відповідні ринки праці, капіталу та інших виробничих ресурсів \\
\hline 2. Виробнича & $\begin{array}{l}\text { Виробництво готової продукції та надання послуг (аграрна продукція, торгів- } \\
\text { ля, будівництво та ін.) }\end{array}$ \\
\hline 3. Споживча & Задоволення потреб домашніх господарств у товарах і послугах \\
\hline 4. Відтворювальна & Накопичення людського капіталу та відтворення робочої сили. \\
\hline $\begin{array}{l}\text { 5. Заощаджувальна } \\
\text { (інвестиційна) }\end{array}$ & Інвестування частини доходів домашніх господарств. \\
\hline 6. Екологічна & $\begin{array}{l}\text { Захист навколишнього природного середовища, раціональне природокористу- } \\
\text { вання, заходи поводження з відходами, використання екологічно безпечних } \\
\text { технологій виробництва. }\end{array}$ \\
\hline 7. Соціальна & $\begin{array}{l}\text { Покращення якості житя, зменшення захворюваності, згуртованість населен- } \\
\text { ня, кооперація. }\end{array}$ \\
\hline
\end{tabular}

"Укладено автором за даними $[6,8]$ 
При цьому покращення якості життя та зменшення захворюваності населення (соціальна функція) досягається впровадженням екологічної функції домогосподарств, зокрема, заходами поводження 3 відходами, використання безпечних технологій виробництва, раціонального природокористування тощо. Вагомою $\epsilon$ екологічна функція домогосподарств у сфері землекористування.
Система індикаторів для діагностики впливу домогосподарств на сталий розвиток економіки наведена в табл. 2. Використовуючи розроблені методичні положення, проведемо діагностику впливу сектору домогосподарств на сталий розвиток економіки України.

\begin{tabular}{|l|}
\hline \multicolumn{1}{|c|}{ ЦСР, завдання } \\
\hline \multicolumn{1}{|c|}{ ЦСР 2 «Подолання голоду, розвиток сільсь- } \\
кого господарства» \\
Завдання 2.2. «Підвищити вдвічі продуктив- \\
ність праці»; 2.3 «Забезпечення створення \\
стійких систем виробництва продуктів харчу- \\
вання» \\
2.1. «Забезпечити доступність збалансованого \\
харчування на рівні науково обгрунтованих \\
норм для всіх верств населення», 2.4. «Знизити \\
волатильність цін на продукти харчування»
\end{tabular}

\section{ЦСР 1 «Подолання бідності»}

Завдання 1.3. «Підвищити життєстійкість соціально вразливих верств населення»; 1.1 «Скоротити в 4 рази рівень бідності, зокрема шляхом ліквідації крайніх її форм»; 1.2 «3більшити охоплення бідного населення адресними програмами соціальної підтримки»

\section{ЦСР 10 «Скорочення нерівності»}

Завдання 10.1. «Забезпечити прискорене зростання доходів найменш забезпечених 40 \% населення»;

Завдання 10.3 «Забезпечити доступність послуг соціальної сфери»

\section{ЦСР 6 «Чиста вода та належні санітарні умови»}

Завдання 6.3 «Зменшити обсяги скидання неочищених стічних вод, насамперед з використанням інноваційних технологій водоочищення на державному та індивідуальному рівнях»

ЦСР 7 «Доступна та чиста енергія» Завдання 7.4 «Підвищити енергоефективність економіки»
Таблиця 2 сектору домогосподарств на сталий розвиток економіки

1. Частка господарств населення у виробництві с/г продукціï, \%*

2. Частка господарств населення у виробництві продукції рослинництва й тваринництва за видами, \%*

3. Індекс с/г продукції господарств населення, \%**

4.Кількість домогосподарств, які мають земельні ділянки, у \% до загальної кількості (у сільській та міській місцевості) 5. Споживання продуктів харчування (за видами) в розрахунку на одну особу, кг/рік*

6.Індекс споживчих цін на продукти харчування (середньорічний), $\%^{* *}$

7. Частка витрат на харчування в сукупних витратах домогосподарств, \%**

8. Частка населення, чиї середньодушові еквівалентні сукупні витрати є нижчими за фактичний (розрахунковий) прожитковий мінімум, \% ${ }^{* *}$

9. Частка бідних, які охоплені державною соціальною підтримкою, в загальній чисельності бідного населення, \% ** 10. Співвідношення рівнів бідності домогосподарств із дітьми та домогосподарств без дітей, рази ${ }^{* *}$

11.Співвідношення темпів зростання середньодушових загальних доходів 40 \% найменш забезпечених та всього населення, \% ${ }^{* *}$

12. Частка сільських домогосподарств, які потерпали від позбавлення через незабезпеченість населеного пункту своєчасними послугами швидкої медичної допомоги, \% ${ }^{* *}$ 13. Частка сільських домогосподарств, які потерпали від позбавлення через відсутність поблизу житла медичної установи, \%**

14. Частка сільських домогосподарств, які потерпали від позбавлення через відсутність регулярного щоденного транспортного сполучення з іншим населеним пунктом 3 розвиненою інфраструктурою, \% ${ }^{* *}$

15. Частка житлового та побутового господарства у загальному обсязі забору прісної води секторами економіки, \% * 16. Частка житлового та побутового господарства у загальному обсязі використання прісної води секторами економіки, \%

17. Частка житлового та побутового господарства у загальному обсязі скидів забруднених стічних вод у водні об'єкти України, \%**

18. Частка скидів забруднених стічних вод у водні об'єкти у загальному обсязі скидів за сектором житлового господарс$\mathrm{TBa}^{* *}$

19. Частка домогосподарств у загальному обсязі кінцевого енергоспоживання в Україні, \%* 
Продовження табл.2

\begin{tabular}{|c|c|}
\hline ЦСР, завдання & Індикатори \\
\hline $\begin{array}{l}\text { ЦСР } 12 \text { «Відповідальне споживання та ви- } \\
\text { робництво» } \\
\text { Завдання } 12.2 \text { «Зменшити втрати продовольс- } \\
\text { тва у виробничо-збутових ланцюжках»; За- } \\
\text { вдання } 12.4 \text { «Зменшити обсяг утворення від- } \\
\text { ходів і збільшити обсяг їх переробки та повто- } \\
\text { рного використання» }\end{array}$ & $\begin{array}{l}\text { 21. Частка післязбиральних втрат у загальному виробництві } \\
\text { овочів та баштанних культур } \\
\text { 22. Частка післязбиральних втрат і витрат на корм у загаль- } \\
\text { ному виробництві плодово-ягідних культур та винограду } \\
\text { 23. Частка сектору домогосподарств у загальному обсязі } \\
\text { утворених відходів, \%* } \\
\text { 24. Індекс ППВ на одну особу, у \% до } 2015 \text { р. }\end{array}$ \\
\hline
\end{tabular}

" Індикатори запропоновано автором;

*** Індикатор за джерелом [3].

У 2020 р. в Україні налічувалося 14,78 млн. домогосподарств, у т.ч. $32,4 \%$ в сільській місцевості (табл. 3). За 2015-2020 pр. їх загальна кількість скоротилася на 1,9\%, сільських - на 3,4 \% (167 тис.). Домогосподарства є основними власниками сільськогосподарських угідь. У 2020 р. земельні ділянки у своє- му користуванні мали 56,2 \% домогосподарств, у міській місцевості - $36 \%$, у сільській - 98,5 \%. Середня площа землі у користуванні одного сільського домогосподарства досягає 282,2 сотки; 73,6 \% селянських господарств утримують худобу, птицю і бджіл [11].

Таблиця 3

Динаміка кількості домогосподарств в Україні, тис. од."

\begin{tabular}{|c|c|c|c|c|c|c|c|}
\hline \multirow{2}{*}{ Показники } & \multicolumn{6}{|c|}{ Роки } & \multirow{2}{*}{$\begin{array}{l}\text { Зміни } \\
(+,-)\end{array}$} \\
\hline & 2015 & 2016 & 2017 & 2018 & 2019 & 2020 & \\
\hline $\begin{array}{l}\text { 1. Кількість домогоспо- } \\
\text { дарств }\end{array}$ & 15073,7 & 15033,4 & 14985,6 & 14934,9 & 14881,7 & 14784,3 & $-289,4$ \\
\hline 1.1. У міській місцевості & 10125,0 & 10109,4 & 10085,5 & 10061,3 & 10037,5 & 10002,2 & $-122,8$ \\
\hline $\begin{array}{l}\text { 1.2. У сільській місцево- } \\
\text { сті }\end{array}$ & 4948,7 & 4924,0 & 4900,1 & 4873,6 & 4844,2 & 4782,1 & $-166,6$ \\
\hline $\begin{array}{l}\text { 2. Кількість домогоспо- } \\
\text { дарств, які мають земельні } \\
\text { ділянки, \% до загальної } \\
\text { кількості }\end{array}$ & 55,2 & 55,6 & 54,9 & 54,7 & 56,8 & 56,2 & $+1,0$ \\
\hline 2.1. У міській місцевості & 34,5 & 34,9 & 34,3 & 33,6 & 36,8 & 36,0 & $+1,5$ \\
\hline $\begin{array}{l}\text { 2.2. У сільській місцево- } \\
\text { сті }\end{array}$ & 97,7 & 98,2 & 97,5 & 98,5 & 98,2 & 98,5 & $+0,8$ \\
\hline
\end{tabular}

*Укладено за даними Державної служби статистики України $[10,11]$

Значною є роль домогосподарств у сталому відтворювальному розвитку аграрного сектору України (табл. 4) та реалізації завдань ЦСР 2 «Подолання голоду, розвиток сільського господарства». Частка гос- подарств населення у виробництві сільськогосподарської продукції в 2019 р. склала 33,9 \%, у т.ч. 30,1% в рослинництві та $48,7 \%$ у тваринництві та має тенденцію до зниження.

Таблиця 4

Частка господарств населення у виробництві аграрної продукції в Україні, \%"

\begin{tabular}{|c|c|c|c|c|c|c|c|c|c|}
\hline \multirow{2}{*}{ Продукція } & \multicolumn{8}{|c|}{ Роки } & \multirow{2}{*}{$\begin{array}{c}\text { Зміни } \\
(+,-)\end{array}$} \\
\hline & 2000 & 2005 & 2010 & 2015 & 2016 & 2017 & 2018 & 2019 & \\
\hline $\begin{array}{l}\text { Аграрна продукція, } \\
\text { всього, у т.ч.: }\end{array}$ & 61,6 & $\mathbf{5 9 , 5}$ & $\mathbf{5 1 , 7}$ & 38,4 & 36,4 & 37,0 & 34,8 & 33,9 & $-27,7$ \\
\hline 1.Продукція рослинництва & 50,7 & 51,4 & 46,4 & 33,9 & 31,9 & 32,6 & 30,5 & 30,1 & $-20,6$ \\
\hline 2. Продукція тваринництва & 79,0 & 73,8 & 61,2 & 52,5 & 52,4 & 52,0 & 50,5 & 48,7 & $-30,3$ \\
\hline
\end{tabular}

*Укладено за даними Державної служби статистики України $[10,12]$ 
Господарства населення спеціалізуються, як правило, на виробництві малорентабельної продукції для внутрішніх потреб населення, виконуючи при цьому важливу функцію забезпечення національної продовольчої безпеки. Частка сектору у виробництві овочевих та плодово-ягідних культур складає 85,3 \% і 83,4 \%, картоплі - 98,2 \%, винограду - 60,7 \%, молока
- 71,8 \% (табл. 5). Слід зазначити, що за 20-річний період частка господарств населення у випуску продукції рослинництва скоротилася на 20,6 \%, тваринництва - на 30,3 \%, що є наслідком перерозподілу ринкових ніш між суб'єктами корпоративного та індивідуального секторів.

Таблиця 5

Питома вага господарств населення у виробництві аграрної продукції в Україні, \%"

\begin{tabular}{|c|c|c|c|c|c|c|c|c|c|}
\hline \multirow{2}{*}{ Продукція } & \multicolumn{8}{|c|}{ Роки } & \multirow{2}{*}{$\begin{array}{l}\text { Зміни } \\
(+,-)\end{array}$} \\
\hline & 2000 & 2005 & 2010 & 2015 & 2016 & 2017 & 2018 & 2019 & \\
\hline $\begin{array}{l}\text { 1. Продукція рослинницт- } \\
\text { ва, всього, у т.ч.: }\end{array}$ & 50,7 & 51,4 & 46,2 & 33,9 & 31,9 & 32,6 & 30,5 & 30,1 & $-20,6$ \\
\hline 1.1.Зернові культури & 18,4 & 24,3 & 24,2 & 22,7 & 21,3 & 22,6 & 19,9 & 20,2 & $+1,8$ \\
\hline $\begin{array}{l}\text { 1.2. Буряк цукровий фабри- } \\
\text { чний }\end{array}$ & 12,2 & 21,5 & 7,9 & 7,5 & 4,7 & 4,4 & 4,7 & 5,4 & $-6,8$ \\
\hline 1.3. Соняшник & 12,5 & 21,2 & 17,5 & 14,6 & 13,9 & 13,4 & 13,9 & 14,2 & $+1,7$ \\
\hline 1.4. Картопля & 98,6 & 98,8 & 97,4 & 97,8 & 97,8 & 98,1 & 98,1 & 98,2 & $-0,4$ \\
\hline 1.5. Культури овочеві & 83,1 & 89,3 & 88,1 & 86,1 & 85,9 & 85,5 & 85,6 & 85,3 & $+2,2$ \\
\hline $\begin{array}{l}\text { 1.6. Культури плодові та } \\
\text { ягідні }\end{array}$ & 81,8 & 88,2 & 83,6 & 80,9 & 81,5 & 83,7 & 78,4 & 83,4 & $+1,6$ \\
\hline 1.7. Виноград & 30,0 & 41,8 & 36,3 & 46,6 & 41,5 & 41,4 & 43,8 & 60,7 & $+30,7$ \\
\hline $\begin{array}{l}\text { 2. Продукція тваринницт- } \\
\text { ва, всього, у т.ч.: }\end{array}$ & 79,0 & 73,8 & 61,3 & 52,5 & 52,4 & 52,0 & 50,5 & 48,7 & $-30,3$ \\
\hline 2.1. М'ясо (у забійній вазі) & 73,7 & 63,2 & 44,9 & 37,0 & 35,9 & 36,0 & 34,9 & 31,9 & $-41,8$ \\
\hline 2.2. Молоко & 71,0 & 81,2 & 80,3 & 74,9 & 73,9 & 73,1 & 72,6 & 71,8 & $+0,8$ \\
\hline 2.3. Яйця & 66,2 & 50,5 & 39,9 & 41,8 & 46,6 & 46,1 & 44,8 & 43,9 & $-22,3$ \\
\hline
\end{tabular}

"Укладено за даними Державної служби статистики України [10, 12]

Характерною особливістю аграрного сектору України є вищий рівень післязбиральних втрат у сегментах овочевих і плодово-ягідних культур, контро- льованих господарствами населення, порівняно 3 індикатором у зерновому сегменті, контрольованому великими агропідприємствами (табл. 6).

Таблиця 6 Динаміка індикаторів втрат продовольства у виробничо-збутових ланцюжках (завдання 12.2 ЦСР 12), \%*

\begin{tabular}{|c|c|c|c|c|c|c|c|c|c|c|}
\hline \multirow{2}{*}{ Індикатори } & \multicolumn{7}{|c|}{ Роки } & \multirow{2}{*}{$\begin{array}{l}\text { Ц3 }^{* *} \\
2025 \\
\text { p. }\end{array}$} & \multicolumn{2}{|c|}{$\begin{array}{l}\text { Відхилення } \\
2019 \text { р. (+, -) }\end{array}$} \\
\hline & 2005 & 2010 & 2015 & 2016 & 2017 & 2018 & 2019 & & $\begin{array}{c}\text { Від } \\
\text { 2015p. }\end{array}$ & Від ЦЗ \\
\hline $\begin{array}{l}\text { 1. Частка втрат у виробни- } \\
\text { цтві зернових культур, \% }\end{array}$ & 1,0 & 2,0 & 2,3 & 2,0 & 1,8 & 1,8 & 1,8 & 1,0 & $-0,5$ & $+0,8$ \\
\hline $\begin{array}{l}\text { 2. Частка втрат у виробни- } \\
\text { цтві овочів та баштанних } \\
\text { культур, \% }\end{array}$ & 5,2 & 9,4 & 12,3 & 12,0 & 10,8 & 10,6 & 12,2 & $\mathbf{7 , 0}$ & $-0,1$ & $+5,2$ \\
\hline $\begin{array}{l}\text { 3. Частка втрат і витрат на } \\
\text { корм у виробництві пло- } \\
\text { дів, ягід і винограду, \% }\end{array}$ & 9,0 & 7,9 & 8,6 & 8,9 & 9,2 & 9,4 & 9,3 & $\mathbf{X}$ & $+0,7$ & $\mathbf{X}$ \\
\hline
\end{tabular}

*Розраховано за даними Державної служби статистики України [10, 13];

**ЦЗ - Цільові значення індикаторів [3, с. 93]. 
Так, у 2019 р. частка втрат у виробництві зернових культур в Україні склала 1,8 \%, що на $0,8 \%$ вище цільового значення індикатора 2025 р., тоді як частка втрат у виробництві овочів та баштанних культур досягла 12,2\%, що на 5,2 \% вище рекомендованого рівня. Питома вага втрат і витрат на корм у виробництві плодів, ягід і винограду у 2019 р. склала 9,3\%, збільшившись порівняно з 2015 р. на $0,7 \%$. Загалом рівень індикаторів втрат продовольства у виробничо-збутових ланцюжках перевищує цільове значення індикатора 2025 р. та є свідченням часткового впровадження завдання 12.2 ЦСР 12 «Відповіда- льне споживання та виробництво», передусім в господарствах населення. Водночас наявна позитивна динаміка до скорочення післязбиральних втрат порівняно з 2015 р. (див. табл. 6).

У 2019 р. індекс аграрної продукції для сектору господарств населення склав $99,1 \%$, що на $2 \%$ менше загального показника для господарств усіх категорій $(101,1 \%)$, та на $2,9 \%$ нижче цільового значення індикатора 2025 р. (табл. 7). Для продукції рослинництва індекс досягнув 100,2\%, збільшившись порівняно з 2015 р. на 4,7\%, тваринництва - 96,7\% за $0,4 \%$-го зростання.

Таблиця 7

Індекси аграрної продукції в сегменті господарств населення в Україні, \%"

\begin{tabular}{|c|c|c|c|c|c|c|c|c|}
\hline \multirow[b]{2}{*}{ Категорії господарств } & \multicolumn{5}{|c|}{ Роки } & \multirow{2}{*}{$\begin{array}{c}\text { Ц3** }^{* *} \\
2025 p .\end{array}$} & \multicolumn{2}{|c|}{$\begin{array}{c}\text { Відхилення } \\
2019(+,)\end{array}$} \\
\hline & 2015 & 2016 & 2017 & 2018 & 2019 & & $\begin{array}{c}\text { Від } \\
2015 \\
\text { p. }\end{array}$ & Від ЦЗ \\
\hline 1.Господарства усіх категорій & 95,2 & 106,3 & 97,8 & 108,2 & 101,1 & 102 & $+5,9$ & $-0,9$ \\
\hline $\begin{array}{l}\text { 2. Господарства населення: про- } \\
\text { дукція сільського господарства, } \\
\text { всього }\end{array}$ & 95,8 & 100,9 & 99,3 & 101,7 & 99,1 & 102 & $+3,3$ & $-2,9$ \\
\hline 2.1. Продукція рослинництва & 95,5 & 102,8 & 99,1 & 103,3 & 100,2 & 102 & $+4,7$ & $-1,8$ \\
\hline 2.2. Продукція тваринництва & 96,3 & 97,2 & 99,6 & 98,1 & 96,7 & 102 & $+0,4$ & $-5,3$ \\
\hline
\end{tabular}

*Укладено за даними Державної служби статистики України [10, 13, 14];

**Ц3 - Цільові значення індикаторів [3, с. 93].

У системі ринкової економіки домогосподарства, окрім виробничої, виконують споживчу функцію, визначаючи ступінь впровадження завдання 2.1 «Забезпечити доступність збалансованого харчування на рівні науково-обгрунтованих норм для всіх верств населення» ЦСР 2. У 2019 р. фактичне споживання населенням України м'яса та м'ясопродуктів склало
75,5\% від цільового значення індикатора 2025 р., молока та молочних продуктів - 62,7 \%, плодовоягідних культур - 75,3\% (табл. 8). Порівняно 3 2015 р. позитивна динаміка змін притаманна споживанню м'ясних продуктів і фруктів (на 3,1 і 22,3 в.п. відповідно), негативна - молочним продуктам (2,9 в.п.).

Таблиця 8

Споживання м'ясо-молочних продуктів та плодово-ягідної продукції населенням України, кг/особу*

\begin{tabular}{|c|c|c|c|c|c|c|c|c|c|c|}
\hline \multirow{2}{*}{ Товари } & \multicolumn{7}{|c|}{ Роки } & \multirow{2}{*}{$\begin{array}{l}\mathbf{3}^{* * *} \\
2025\end{array}$} & \multicolumn{2}{|c|}{2019 р. у \% до: } \\
\hline & 2005 & 2010 & 2015 & 2016 & 2017 & 2018 & 2019 & & $2015 p$. & $\begin{array}{c}\text { Ц3 } \\
2025 \mathrm{p} .\end{array}$ \\
\hline $\begin{array}{l}\text { 1. М'ясо і } \\
\text { м'ясопродукти }\end{array}$ & 39,1 & 52 & 50,9 & 51,4 & 51,7 & 52,8 & 53,6 & 71 & 103,1 & 75,5 \\
\hline $\begin{array}{l}\text { 2. Молоко і молочні } \\
\text { продукти }\end{array}$ & 225,6 & 206,4 & 209,9 & 209,5 & 200 & 197,7 & 200,5 & 320 & 97,1 & 62,7 \\
\hline $\begin{array}{l}\text { 3.Плоди, ягоди та ви- } \\
\text { ноград (без переробки } \\
\text { на вино) }\end{array}$ & 37,1 & 48 & 50,9 & 49,7 & 52,8 & 57,8 & 58,7 & 78 & 122,3 & 75,3 \\
\hline
\end{tabular}

* Укладено за даними Державної служби статистики України [10, 13, 14];

**Ц3 - Цільові значення індикаторів 2025 р. [3, с. 21].

Одним із головних чинників впливу на обсяги споживання продуктів харчування домогосподарствами є ціновий, відтак, маємо взаємопов'язаність завдань 2.1. і 2.4. «Знизити волатильність цін на продукти харчування» ЦСР 2. У 2019 р. порівняно 3
2015 р. рівні індексів споживчих цін істотно знизилися за всіма групами продовольчих товарів (окрім овочів), водночас вони за більшістю товарних груп перевищили цільовий орієнтир 2025 р. в $105 \%$.

Наслідком значної цінової волатильності на 
агропродовольчих ринках України та перманентного зростання цін на продукти харчування є досить знач- на частка витрат на харчування в сукупних витратах домогосподарств (табл. 9).

Частка витрат на харчування в сукупних витратах домогосподарств в Україні, \%*

\begin{tabular}{|c|c|c|c|c|c|c|c|c|}
\hline \multirow{2}{*}{ Показник } & \multicolumn{5}{|c|}{ Роки } & \multirow{2}{*}{$\begin{array}{l}Ц 3^{* *} \\
2025\end{array}$} & \multicolumn{2}{|c|}{$\begin{array}{c}\text { Відхилення 2019p. }(+,-) \\
\text { від: }\end{array}$} \\
\hline & 2015 & 2016 & 2017 & 2018 & 2019 & & 2015 & ЦЗ 2025 \\
\hline Усього, в тому числі: & 54,6 & 51,4 & 49,6 & 49,4 & 48,5 & 40 & $-6,1$ & $+8,5$ \\
\hline у міській місцевості & 53,5 & 50,3 & 48,7 & 48,4 & 47,1 & 40 & $-6,4$ & $+7,1$ \\
\hline у сільській місцевості & 57,2 & 53,9 & 51,7 & 51,7 & 51,4 & 40 & $-5,8$ & $+11,4$ \\
\hline
\end{tabular}

Укладено за даними Державної служби статистики України $[10,14]$;

**Ц3 - Цільові значення індикаторів 2025 р. [3, с. 15].

У 2019 р. даний індикатор склав 48,5 \%, при цьому у сільській місцевості його рівень $(51,4 \%) \epsilon$ вищим, ніж у міській $(47,1$ \%). Незважаючи на тенденцію до зниження, величина індикатора перевищила цільовий орієнтир 2025 р. (40\%), що свідчить про часткову реалізацію завдання 1.3 «Підвищити життєстійкість соціально вразливих верств населення»

\section{ЦСР 1 в державі.}

Група індикаторів, що відображають динаміку впровадження завдань ЦСР 1 «Подолання бідності» в Україні, та характеризують соціальну функцію домогосподарств в аспекті підвищення якості життя, узагальнена в табл. 10.

Динаміка індикаторів для діагностики ЦСР 1 «Подолання бідності» в Україні, \%"

Таблиця 10

\begin{tabular}{|c|c|c|c|c|c|c|c|c|}
\hline \multirow{2}{*}{ Індикатори } & \multicolumn{5}{|c|}{ Роки } & \multirow{2}{*}{$\begin{array}{l}\bigsqcup^{* *} \\
2025 p .\end{array}$} & \multicolumn{2}{|c|}{$\begin{array}{c}\text { Відхилення } \\
\text { 2019p. (+,-) від: }\end{array}$} \\
\hline & 2015 & 2016 & 2017 & 2018 & 2019 & & $2015 \mathrm{p}$. & ЦЗ \\
\hline $\begin{array}{l}\text { 1. Частка населення, чиї серед- } \\
\text { ньодушові еквівалентні сукупні } \\
\text { витрати є нижчими за фактичний } \\
\text { (розрахунковий) прожитковий } \\
\text { мінімум }\end{array}$ & 58,3 & 58,6 & 47,3 & 43,2 & 41,3 & 20 & -17 & $+21,3$ \\
\hline 1.1. Домогосподарства 3 дітьми & 66,5 & 65,2 & 55,1 & 49,9 & 47,3 & 20 & $-19,2$ & $+27,3$ \\
\hline $\begin{array}{l}\text { 1.2. Домогосподарства без ді- } \\
\text { тей }\end{array}$ & 48,8 & 50,9 & 38,1 & 35,4 & 34,3 & 20 & $-14,5$ & $+14,3$ \\
\hline $\begin{array}{l}\text { 2.Частка бідних, які охоплені } \\
\text { державною соціальною підтрим- } \\
\text { кою, в загальній чисельності бід- } \\
\text { ного населення } \\
\end{array}$ & 63,0 & 70,3 & 73,6 & 72,0 & 57,4 & 75 & $-5,6$ & $-17,6$ \\
\hline $\begin{array}{l}\text { 3. Співвідношення рівнів бідності } \\
\text { домогосподарств із дітьми та до- } \\
\text { могосподарств без дітей, рази: }\end{array}$ & 1,5 & 1,4 & 1,6 & 1,5 & 1,2 & 1,4 & $-0,3$ & $-0,2$ \\
\hline 3.1. У міській місцевості & 1,4 & 1,4 & 1,6 & 1,5 & 1,2 & 1,4 & $-0,2$ & $-0,2$ \\
\hline 3.2. У сільській місцевості & 1,5 & 1,5 & 1,6 & 1,6 & 1,3 & 1,4 & $-0,2$ & $-0,1$ \\
\hline
\end{tabular}

"Укладено за даними Державної служби статистики України [10, 14];

**ЦЗ - Цільові значення індикаторів 2025 р. [3, с. 15].

У 2019 р. частка населення, чиї сукупні витрати $є$ нижчими за фактичний прожитковий мінімум, склала $\mathbf{4 1 , 3} \%$, практично вдвічі перевищивши цільове значення індикатора 2025 р. (20\%), при цьому його рівень $є$ вищим у домогосподарствах 3 дітьми (47,3\%). Частка бідних, які охоплені державною соціальною підтримкою, в звітному році склала $\mathbf{5 7 , 4} \%$, зменшившись порівняно з 2015 р. на 5,6 в.п., однак не досягла цільового орієнтиру 2025 р. (75\%). У 2019 р. співвідношення рівнів бідності домогосподарств із дітьми та домогосподарств без дітей склало 1,2 рази, у т.ч. в сільській місцевості - 1,3 рази, не тільки досягнувши, а й покращивши цільове значення індикатора (див. табл. 10). Відтак, значення індикаторів, які характеризують стан виконання завдань 1.1. і 1.2 ЦСР 1 в Україні $\epsilon$ незадовільними та не відповідають цільовим орієнтирам 2025 p. 
Логічним продовженням діагностики впливу сектору домогосподарств на сталий розвиток економіки в аспекті розкриття їх соціальної функції $є$ оцін- ка індикаторів для впровадження завдань ЦСР 10 «Скорочення нерівності». Їх динаміка за 20152019 рр. наведена в табл. 11.

Таблиця 11

Динаміка індикаторів для діагностики ЦСР 10 «Скорочення нерівності» в Україні, \%*

\begin{tabular}{|c|c|c|c|c|c|c|c|c|}
\hline \multirow[t]{2}{*}{ Індикатори } & \multicolumn{5}{|c|}{ Роки } & \multirow{2}{*}{$\begin{array}{l}\text { Ц3** } \\
2025\end{array}$} & \multicolumn{2}{|c|}{$\begin{array}{c}\text { Відхилення } \\
\text { 2019p. }(+,-) \\
\text { від: } \\
\end{array}$} \\
\hline & 2015 & 2016 & 2017 & 2018 & 2019 & & $\begin{array}{c}\text { Від } \\
2015 \text { p. }\end{array}$ & Від Ц3 \\
\hline $\begin{array}{l}\text { 1.Співвідношення темпів зростання се- } \\
\text { редньодушових загальних доходів } 40 \text { \% } \\
\text { найменш забезпечених та всього насе- } \\
\text { лення }\end{array}$ & 0,99 & 1,02 & 0,97 & 0,95 & 0,97 & $\mathrm{X}$ & $-0,02$ & $\mathrm{X}$ \\
\hline 1.1. У міській місцевості & 1,03 & 0,98 & 0,97 & 0,91 & 0,98 & $\mathrm{X}$ & $-0,05$ & $\mathrm{X}$ \\
\hline 1.2. У сільській місцевості & 1,05 & 1,01 & 0,9 & 0,9 & 0,96 & $\mathrm{X}$ & $-0,09$ & $\mathrm{X}$ \\
\hline $\begin{array}{l}\text { 2.Частка сільських домогосподарств, які } \\
\text { потерпали від позбавлення через неза- } \\
\text { безпеченість населеного пункту своєча- } \\
\text { сними послугами швидкої медичної } \\
\text { допомоги }\end{array}$ & 39,9 & н.д. & 38,2 & н.д. & 39,2 & 20 & $-0,7$ & $+19,2$ \\
\hline $\begin{array}{l}\text { 3. Частка сільських домогосподарств, } \\
\text { які потерпали від позбавлення через } \\
\text { відсутність поблизу житла медичної } \\
\text { установи }\end{array}$ & 26,3 & н.д. & 27,8 & н.Д. & 29,6 & 15 & $+3,3$ & $+14,6$ \\
\hline $\begin{array}{l}\text { 4.Частка сільських домогосподарств, які } \\
\text { потерпали від позбавлення через відсу- } \\
\text { тність регулярного щоденного транспо- } \\
\text { ртного сполучення з іншим населеним } \\
\text { пунктом з розвиненою інфраструктурою }\end{array}$ & 22,7 & н.д. & 22,5 & н.д. & 24,4 & 13 & 1,7 & $+11,4$ \\
\hline
\end{tabular}

"Укладено за даними Державної служби статистики України [10, 14];

**Ц3 - Цільові значення індикаторів 2025 р. [3, с. 79].

Значення індикаторів, які характеризують стан виконання завдань 10.1. і 10.3 ЦСР 10, не відповідають цільовим орієнтирам 2025 р. (див. табл. 11), що є свідченням низького ступеня реалізації даних завдань в Україні.

Виконуючи споживчу функцію в ринковій економіці, сектор домогосподарств $є$ вагомим споживачем водних та енергетичних ресурсів, відтак, впли- ває на стан досягнення завдань ЦСР 6 «Чиста вода та належні санітарні умови» і ЦСР 7 «Доступна та чиста енергія». Для діагностики реалізації ЦСР 6 у секторальному вимірі Державна служба статистики оперує даними для сектору житлового та побутового господарства, який водночас відображає головні тенденції водоспоживання домогосподарств України (рис. 2).

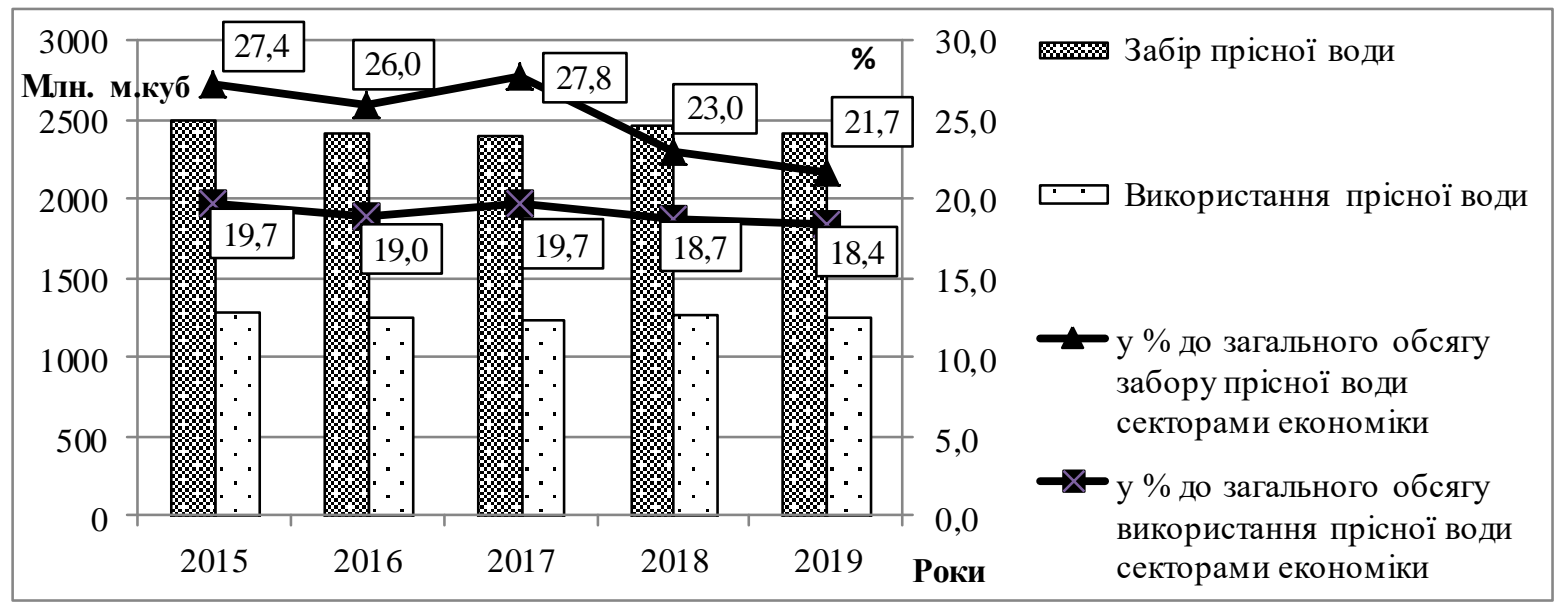

Рис. 2. Динаміка часток житлового та побутового господарства у загальному обсязі забору та використання прісної води секторами економіки України"

*Розраховано за даними Державної служби статистики України $[15,16]$ 
Так, у 2019 р. забір прісної води у секторі житлового та побутового господарства склав 2411 млн. куб. м, або 21,7 \% від загального обсягу забору води секторами національної економіки. При цьому використання прісної води житловим господарством досягло 1254 млн. куб. м., або 18,4 \% від загального обсягу використання прісної води секторами економіки. За 2015-2019 рр. наявна тенденція до скорочення обсягів забору та використання прісної води у секторі житлового господарства, а також його частки у загальних обсягах (див. рис. 2).

В Україні сектор житлового та побутового господарства $є$ головним забруднювачем водним ресур- сів, у 2019 р. на його частку припадало 76,5 \% обсягів скидів забруднених стічних вод (табл. 12). За 20152019 pp. частка житлового господарства зросла на 41,3\% на фоні зменшення часток інших секторів економіки. У звітному році обсяги скидів забруднених стічних вод у водні об'єкти в секторі житлового господарства зросли на 83 \%, в інших секторах економіки (окрім аграрного) вони мали знижувальний тренд. У 2019 р. обсяги скидів забруднених стічних вод у водні об'єкти України досягли 737,2 млн. куб. м, що на 180,2 млн. куб м або 24,5 \% вище цільового значення індикатора 2025 р. (557 млн. куб. м) [3].

Таблиця 12

Динаміка та структура скидів забруднених стічних вод у водні об'скти України в секторальному в имірі, млн. куб. м*

\begin{tabular}{|c|c|c|c|c|c|c|}
\hline \multirow{2}{*}{ Сектори економіки } & \multicolumn{5}{|c|}{ Роки } & \multirow{2}{*}{$\begin{array}{l}2019 \text { p. у \% } \\
\text { до } 2015 \text { p. }\end{array}$} \\
\hline & 2015 & 2016 & 2017 & 2018 & 2019 & \\
\hline $\begin{array}{l}\text { Обсяги скидів забруднених (забруднених } \\
\text { без очистки та недостатньо очищених) } \\
\text { стічних вод у водні об'єкти, млн. куб. м }\end{array}$ & 875,1 & 698,3 & 997,3 & 952 & 737,2 & 84,2 \\
\hline 1. Промисловість & 481,3 & 327,3 & 311,1 & 301,4 & 91,54 & 19,0 \\
\hline 2. Сільське господарство & 24,68 & 22,31 & 28,9 & 15,37 & 46,5 & 188,4 \\
\hline 3. Транспорт & 3,08 & 2,05 & 1,95 & 2,79 & 0,398 & 12,9 \\
\hline 4. Торгівля і громадське харчування & 55,22 & 50,72 & 46,18 & 45,73 & 33,88 & 61,4 \\
\hline 5.Житлове та побутове господарство & 308,1 & 294,3 & 607,5 & 585,3 & 563,7 & 183,0 \\
\hline 6. Інші сектори & 2,72 & 1,62 & 1,67 & 1,41 & 1,182 & 43,5 \\
\hline \multicolumn{6}{|c|}{ Секторальна структура скидів забруднених стічних вод у водні об’єкти, \% } & $\begin{array}{l}\text { Динаміка } \\
\text { змін }(+,-)\end{array}$ \\
\hline 1. Промисловість & 55,00 & 46,87 & 31,19 & 31,66 & 12,42 & $-42,58$ \\
\hline 2. Сільське господарство & 2,82 & 3,19 & 2,90 & 1,61 & 6,31 & $+3,49$ \\
\hline 3. Транспорт & 0,35 & 0,29 & 0,20 & 0,29 & 0,05 & $-0,30$ \\
\hline 4. Торгівля і громадське харчування & 6,31 & 7,26 & 4,63 & 4,80 & 4,60 & $-1,71$ \\
\hline 5.Житлове та побутове господарство & 35,21 & 42,15 & 60,91 & 61,48 & $\mathbf{7 6 , 4 7}$ & $+41,26$ \\
\hline 6. Інші сектори & 0,31 & 0,23 & 0,17 & 0,15 & 0,16 & $-0,15$ \\
\hline
\end{tabular}

"Укладено за даними Державної служби статистики України [10, 14]

Інституційний сектор домогосподарств входить до складу найбільших споживачів енергії в Україні. У 2018 р. в структурі кінцевого енергоспоживання він посів друге місце із часткою $31,7 \%$, перше місце зайняв промисловий сектор (32,2\%). У звітному році домашні господарства спожили 16203 тис. т н.е. енергії, що на 2,1\% менше рівня 2015 р. За досліджуваний період питома вага сектору домогосподарств зросла на 0,9 в.П. [4].
Сектор домогосподарств є споживачем природних ресурсів та чинить антропогенний вплив на природне середовище. У 2019 р. у секторальній структурі утворених відходів на частку домогосподарств припадало 1,3\%, що на 0,6 в.п. нижче рівня 2015 р. (табл. 13). У звітному році загальний обсяг утворених ППВ в Україні склав 6,62 млн. т, на одну особу 157,5 кг.

Динаміка утворених відходів у секторі домогосподарств України, тис. т*

\begin{tabular}{|c|c|c|c|c|c|c|c|}
\hline \multirow{2}{*}{ Показники } & \multicolumn{6}{|c|}{ Роки } & \multirow{2}{*}{$\begin{array}{l}2019 \text { p. y \% } \\
\text { до } 2015 \text { p. }\end{array}$} \\
\hline & 2010 & 2015 & 2016 & 2017 & 2018 & 2019 & \\
\hline $\begin{array}{l}\text { 1. Обсяги утворених відходів у сек- } \\
\text { торі домогосподарств }\end{array}$ & 6722,4 & 6053,3 & 6346,5 & 5858,0 & 5543,5 & 5896,7 & 97,4 \\
\hline $\begin{array}{l}\text { y\% до загального обсягу утво- } \\
\text { рених відходів в економіці }\end{array}$ & 1,59 & 1,94 & 2,15 & 1,60 & 1,34 & 1,30 & $X$ \\
\hline 2. Обсяг утворених ППВ ${ }^{* *}$ в Україні & 7611,6 & 6789,2 & 6946,2 & 6183,2 & 6211,2 & 6618,0 & 97,5 \\
\hline 3. Утворено ППВ на 1 особу, кг & 165,9 & 158,5 & 162,8 & 145,5 & 146,9 & 157,5 & 99,4 \\
\hline
\end{tabular}

*Розраховано за даними Державної служби статистики України $[10,15,16]$;

** ППВ - побутові та подібні відходи. 
Сьогодні проблема управління побутовими відходами залишається однією 3 найбільш актуальних господарських і екологічних проблем. В Україні тіль- ки $78 \%$ населення забезпечено послугами з вивезення ППВ, що обумовлено, передусім, нерозвиненістю інфраструктури для їх переробки та утилізації [3].

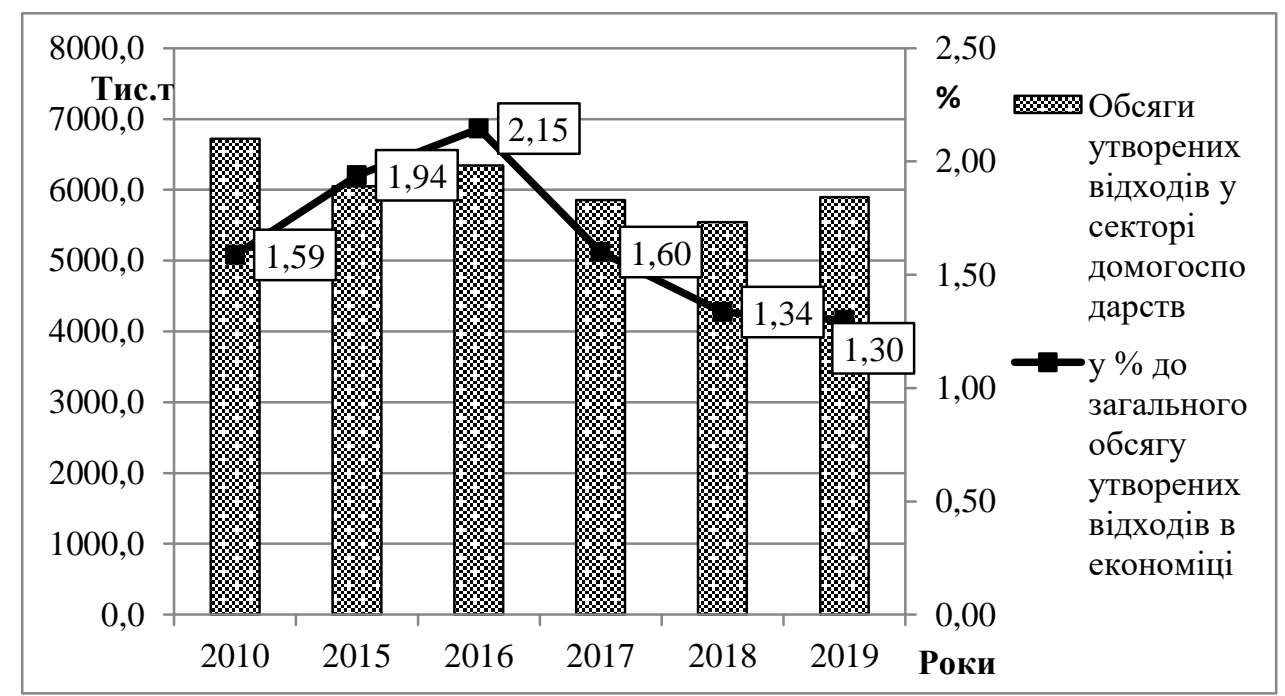

Рис. 3. Динаміка обсягів та частки утворених відходів у секторі домогосподарств України* *побудовано автором за даними табл. 13.

Для впровадження концепції сталого споживання необхідним є поширення екологічної обізнаності серед домогосподарств, яку вони втілюватимуть у своєму виробництві та споживанні.

Висновки та перспективи подальших досліджень. У ході дослідження встановлено, що інституційний сектор домогосподарств є учасником ІІПП, впливаючи на сталий розвиток національної економіки. Доповнено головні функції домогосподарств у ринковій економіці екологічною та соціальною функціями. Розроблено методичне забезпечення діагностики впливу сектору домашніх господарств на сталий розвиток економіки у координатах завдань і ЦСР 1, 2, $6,7,10,12$. Особливістю авторського методичного підходу $\epsilon$ інтеграція до системи індикаторів сталого розвитку низки секторальних показників, які дозволяють діагностувати тенденції сталого розвитку сектору домашніх господарств і господарств населення. Використовуючи запропоноване методичне забезпечення, проведено діагностику впливу інституційного сектору домогосподарств на сталий розвиток економіки України за 2015-2019 рр., що дозволило визначити роль даного сектору у впровадженні ЦСР.

У ході діагностики встановлено вагомий вплив господарств населення на сталий відтворювальний розвиток аграрної сфери України. У 2019 р. господарства населення виробляли 33,9 \% сільгосппродукції, займаючи ринкові ніші плодово-овочевої продукції (83-98 \%) та молока (72 \%). За 2000-2019 рр. частка індивідуального сектору у виробництві аграрної продукції скоротилася майже на 30 \%; індекси продукції не досягли цільового значення 2025 р. Споживання головних продуктів харчування населенням України на 25-37 \% є нижчим цільового індикатора 2025 р.; частка витрат на харчування у сукупних витратах домогосподарств досягає 48,5\%, перевищуючи на $8,5 \%$ цільовий рівень. Значення індикаторів ЦСР 1 «Подолання бідності» та 10 «Скорочення нерівності» не відповідають цільовим орієнтирам 2025 р., що $є$ свідченням низького ступеня реалізації завдань даних Цілей сталого розвитку в Україні.

Виконуючи споживчу функцію в ринковій економіці, сектор домогосподарств $є$ вагомим споживачем водних та енергетичних ресурсів. Питома вага житлового та побутового господарства у загальному обсязі забору та використання прісної води в 2019 р. склала 21,7 \% та 18,4 \% відповідно та має знижувальний тренд. Даний сектор є головним забруднювачем водних ресурсів в Україні, продукуючи 76,5 \% скидів забруднених стічних вод у водні об'єкти, що на $41 \%$ вище рівня 2015 р. Частка сектору домогосподарств у загальному обсязі кінцевого енергоспоживання досягає близько $31 \%$. Як споживач природних ресурсів, даний сектор чинить антропогенний вплив на навколишнє середовище, зокрема, у сфері поводження 3 відходами. У 2019 р. частка сектору домогосподарств у загальному обсязі утворених відходів склала 1,3\% та має знижувальний тренд. Водночас проблема управління побутовими відходами в Україні залишається невирішеною, обумовлюючи необхідність впровадження положень Національної стратегії управління відходами в Україні до 2030 р. №820-р, зокрема, в частині збільшення обсягів переробки відходів до 50 \% в 2030 р., створення 800 од. потужностей з переробки вторинної сировини [17].

Наукова новизна проведеного дослідження полягає у вдосконаленні методичного базису діагностики впливу сектору домашніх господарств на сталий 
розвиток економіки, розробці та апробації нових індикаторів, що дозволяють визначити місце і роль даного інституційного сектору в реалізації завдань ЦСР в українських реаліях. Практичне значення методичного забезпечення та результатів діагностики визначається можливістю їх використання державними й регіональними органами влади, суб'єктами господарювання та іншими стейкхолдерами в ході діагностики сучасних тенденцій і проблем сталого розвитку в секторальному вимірі, як аналітичного підгрунтя для впровадження адаптивних механізмів і заходів регулювання. Перспективи подальших досліджень полягають у розширенні методичного базису за рахунок нових індикаторів діагностики впливу сектору домогосподарств на сталий розвиток економіки для розбудови системи багаторівневого моніторингу ЦСР в Україні.

\section{Література}

1. Про всеукраїнський перепис населення: Закон України №2058-III від 19.10.2000 р.: за станом на 02.12.2012 p. URL: https://zakon.rada.gov.ua/laws/show/2058-14\#Tехt (дата звернення: 22.07.2021)

2. Класифікація інституційних секторів економіки України: затверджена наказом Держстату від 03.12.2014 № 378 (зі змінами, затвердженими наказом Держстату від 25.02.2020 № 85). URL: https://zakon.rada.gov.ua/rada/show/v0378832-14\#Text (дата звернення: 22.07.2021)

3. Цілі Сталого Розвитку: Україна: Національна доповідь 2017. Міністерство економічного розвитку і торгівлі України, 2017. 176 с.

4. Буркинський Б.В., Нікішина О.В. Методичні рекомендації до комплексної оцінки домінант інвестиційно-інноваційної політики природокористування національної економіки: наук. доповідь. Одеса: ІПРЕЕД НАН України, 2020. 195 с.

5. Андрєєва Н.М., Тютюнник Г.О. Методичні підходи щодо визначення домінант регіональної інвестиційно-інноваційної політики природокористування: наукова доповідь. Одеса: ІПРЕЕД НАН України, 2020. $101 \mathrm{c}$.

6. Бурляй А.П., Бурляй О.Л., Рябченко О.О. Роль сільських домогосподарств у сталому розвитку України. Науковий вісник Ужгородського національного університету. 2018. Вип. 18. Ч. 1. С.58-62.

7. Кришеник Н.І. Домогосподарства в системі використання та охорони земель. Східна Європа: Економіка, бізнес та управління. 2017. Вип. 6 (11). С.256-259.

8. Кізима Т.О. Домогосподарство як інституційна економічна одиниця та суб'єкт фінансових відносин // Наукові записки. Сер. .Економіка. Вип. 10. 2008. С.134-144.

9. Carayannis, E. G. Bart, T.D., Campbell D.F.J. The quintuple helix innovation model: global warning as a challenge and driver for innovation // Journal of Innovation and Entrepreneurship. 2012. № 1(1). P. 1-12. doi: 10.1186/2192-5372-1-2

10. Офіційний сайт Державної служби статистики України: [Веб-сайт]. URL: http://www.ukrstat.gov.ua/ (дата звернення: 25.07.2021)

11. Соціально-демографічні характеристики домогосподарств у 2020 р.: статистичний збірник. Київ: Державна служба статистики України, 2020. 88 с.

12. Статистичний щорічник України за 2019 рік / за ред. І.Є.Вернера. Київ: Державна служба статистики України, 2020. 465 с.

13. Баланси та споживання основних продуктів харчування населенням України: стат. збірник. Відп. за випуск О.М. Прокопенко. Київ: Державна служба статистики України, 2020. 60 с.

14. Цілі сталого розвитку Україна 2020 р.: моніторинговий звіт. К.: Державна служба статистики України, ЮНІСЕФ. 92 с.

15. Довкілля України за 2018 рік: статистичний збірник. За ред. О. М. Прокопенко. Київ: Державна служба статистики України, 2019. 214 с.

16. Довкілля України за 2019 рік: статистичний збірник. За ред. О. М. Прокопенко. Київ: Державна служба статистики України, 2020. 213 с.

17. Національна стратегія управління відходами в Україні до 2030 року: схвалена розпорядженням Кабінету Міністрів України від 8 листопада 2017 р. № 820-p. URL: https://zakon.rada.gov.ua/laws/show/820-2017$\% \mathrm{D} 1 \% 80 \#$ Text (дата звернення: 25.07.2021) 


\author{
Nikishyna 0. \\ Doctor of Economics, Senior Researcher \\ Head of Department of Market Mechanisms and Structures \\ Institute of Market Problems and Economic \& Ecological Research \\ of National Academy of Sciences of Ukraine \\ Frantsuzskiy boulevard, 29, Odesa, Ukraine, 65044 \\ E-mail: ksenkych@gmail.com \\ ORCID ID: 0000-0002-7172-3551
}

\title{
DIAGNOSIS OF THE IMPACT OF THE INSTITUTIONAL SECTOR OF HOUSEHOLDS ON THE SUSTAINABLE DEVELOPMENT OF UKRAINE'S ECONOMY
}

The article is devoted to the substantiation of methodological support for diagnosing the impact of the household sector on sustainable development of the national economy in the coordinates of Sustainable Development Goals 1, 2, 6, 7, 10,12. It has been emphasized that this methodological basis is a component of the general methodology economy. The basic functions of households in a market economy have been supplemented by environmental and social functions. A feature of the author's methodological support is the integration into the national system of indicators of sustainable development of a number of sectoral indicators that allow diagnosing trends in sustainable development of the household sector.

Based on the developed guidelines, the impact of the institutional sector of households on the sustainable development of Ukraine's economy for 2015-2019 was diagnosed, which allowed to determine the place and role of this sector in the implementation of the Sustainable Development Goals. Based on the diagnostic results, the main trends and problems of sustainable development of the household sector has been substantiated. Thus, a significant impact of households on the sustainable reproduction development of the agricultural sector of Ukraine has been established. In 2019, households produced almost $34 \%$ of agricultural products, ensuring food security in the segments of fruits and vegetables and milk; at the same time, the indices of their products did not reach the target level of 2025. The values of the indicators of Sustainable Development Goals 1 «Overcoming Poverty» and 10 «Reducing Inequality» do not meet the targets of 2025, which is evidence of low implementation of these Goals in Ukraine.

The study found that the household sector is the main polluter of water resources, generating almost $77 \%$ of discharges of contaminated wastewater into water bodies of Ukraine. The share of the household sector in the total amount of generated waste is $1,3 \%$ and has a downward trend. The solution to the problem of household waste management lies in the development of infrastructure for their processing and disposal.

The applied value of methodological support and diagnostic results is determined by the possibility of their use by state and regional authorities, businesses and other stakeholders in the diagnosis of current trends and problems of sustainable development in the sectoral dimension, as an analytical basis for implementing adaptive mechanisms and regulation measures in conditions of instability.

Key words: sector, households, household economy, Sustainable development goals, diagnostics, indicators.

\section{References}

1. Pro vseukrainskyi perepys naselennia: Zakon Ukrainy №2058-III vid 19.10.2000 r.: za stanom na 02.12.2012 $r$. Retrieved July 22, 2021, from https://zakon.rada.gov.ua/laws/show/2058-14\#Text

2. Klasyfikatsiia instytutsiinykh sektoriv ekonomiky Ukrainy: zatverdzhena nakazom Derzhstatu vid 03.12.2014 № 378 (zi zminamy, zatverdzhenymy nakazom Derzhstatu vid 25.02.2020 № 85). Retrieved July 22, 2021, from https://zakon.rada.gov.ua/rada/show/v0378832-14\#Text

3. Ministerstvo ekonomichnoho rozvytku i torhivli Ukrainy. (2017). (rep.). Tsili Staloho Rozvytku: Ukraina (pp. 1-176).

4. Burkynskyi, B. V., \& Nikishyna, O. V. (2020). (rep.). Metodychni rekomendatsii do kompleksnoi otsinky dominant investytsiino-innovatsiinoi polityky pryrodokorystuvannia natsionalnoi ekonomiky. (pp. 1-195). Odesa: IPREED NAN Ukrainy.

5. Andrieieva, N. M., \& Tiutiunnyk, H. O. (2020). (rep.). Metodychni pidkhody shchodo vyznachennia dominant rehionalnoi investytsiino-innovatsiinoi polityky pryrodokorystuvannia. (pp. 1-101). Odesa: IPREED NAN Ukrainy.

6. Burliai, A. P., Burliai, O. L., \& Riabchenko, O. O. (2018). Rol silskykh domohospodarstv u stalomu rozvytku Ukrainy. Naukovyi visnyk Uzhhorodskoho natsionalnoho universytetu, (18), Ch. 1, 58-62. 
7. Kryshenyk, N. I. (2017). Domohospodarstva v systemi vykorystannia ta okhorony zemel. Skhidna Yevropa: Ekonomika, biznes ta upravlinnia, 6 (11)), 256-259.

8. Kizyma, T. O. (2008). Domohospodarstvo yak instytutsiina ekonomichna odynytsia ta sub'iekt finansovykh vidnosyn. Naukovi zapysky, (10), 134-144.

9. Carayannis, E. G., Bart, T.D., \& Campbell, D.F.J. (2012). The quintuple helix innovation model: global warning as a challenge and driver for innovation. Journal of Innovation and Entrepreneurship, (1(1)), 1-12. doi: $10.1186 / 2192-5372-1-2$

10. Ofitsiinyi sait Derzhavnoi sluzhby statystyky Ukrainy. Retrieved July 25, 2021, from http://www.ukrstat.gov.ua/

11. Derzhavna sluzhba statystyky Ukrainy. (2020). Sotsialno-demohrafichni kharakterystyky domohospodarstv u 2020 r..: statystychnyi zbirnyk.

12. Vernera, I. Ye. (Ed.). (2020). Statystychnyi shchorichnyk Ukrainy za 2019 rik. Derzhavna sluzhba statystyky Ukrainy.

13. Prokopenko, O. M. (2020). Balansy ta spozhyvannia osnovnykh produktiv kharchuvannia naselenniam Ukrainy: stat. zbirnyk. Derzhavna sluzhba statystyky Ukrainy.

14. Derzhavna sluzhba statystyky Ukrainy, YuNISEF. (rep.). Tsili staloho rozvytku Ukraina 2020 r. (pp. 1 92). Kyiv.

15.Prokopenko, O. M. (Ed.). (2019). Dovkillia Ukrainy za 2018 rik: statystychnyi zbirnyk. Derzhavna sluzhba statystyky Ukrainy.

16. Prokopenko, O. M. (Ed.). (2020). Dovkillia Ukrainy za 2019 rik: statystychnyi zbirnyk. Derzhavna sluzhba statystyky Ukrainy.

17. Natsionalna stratehiia upravlinnia vidkhodamy v Ukraini do 2030 roku: skhvalena rozporiadzhenniam Kabinetu Ministriv Ukrainy vid 8 lystopada 2017 r. № 820-r. Retrieved July 25, 2021, from https://zakon.rada.gov.ua/laws/show/820-2017-\%D1\%80\#Text

Received 10 August 2021 Approved 24 August 2021 Available in Internet 24.10.2021

Цитування згідно ДСТУ 8302:2015

Нікішина О.В. Діагностика впливу інституційного сектору домогосподарств на сталий розвиток економіки України // Економіка харчової промисловості. 2021. Т. 13, вип. 3. С. 3-15. doi: 10.15673/fie.v13i3.2127

Cite as APA style citation

Nikishyna, O. (2021). Diagnosis of the impact of the institutional sector of households on the sustainable development of Ukraine's economy. Food Industry Economics, 13(3), 3-15. doi: 10.15673/fie.v13i3.2127 